The presence of $(\mathrm{dA} . \mathrm{dT})_{20-25}$ tracts in the DNA of primitive eukaryotes

J.N.M.Mol, R.A. Flavell and P.Borst

Sect.for Med.Enzymol. and Mol.Biol., Lab. Biochem., University of Amsterdam, Eerste Constantijn Huygensstraat 20, Amsterdam, The Netherlands

Received 28 June 1976

ABSTRACT

Previous work by Jacobson et al. (1) has shown that the number and distribution of (dA.dT) 25 tracts in the nuclear DNA of the slime mold Dictyostelium discoideum reflects the number and the distribution of transcriptional units. To investigate whether this is a general phenomenon we compared the nuclear DNAs of other primitive eukaryotes with respect to their content of large (dA.dT) tracts via the thermal stability of their hybrids with poly $(r A)$. The results of our analysis indicate that all nuclear DNAs tested have (dA.dT) 20-25 tracts, but the frequency of such tracts varies from one per $5.4 \times 106$ daltons in Dictyostelium nuclear DNA to one per $2.8 \times 10^{8}$ daltons in Crithidia luciliae nuclear DNA. We conclude that the presence of (dA.dT) 20-25 tracts is not an obligatory characteristic of the transcriptional unit in primitive eukaryotes.

Chromatography of native DNAs on poly(rU) Sephadex columns shows that the large (dA.dT) tracts occurring in the genomes of both primitive and higher eukaryotes are widely distributed throughout these genomes.

\title{
INTRODUCTION
}

The genome of several eukaryotes contains a high frequency of $(d A . d T)$-rich sequences $(2,3)$. Detailed information about the length of these tracts, their position in the DNA and their possible function is only available for the nuclear DNA of the slime mold Dictyostelium discoideum. In this case the tracts, which make up 0.38 of the DNA, are homogeneous in size and widely distributed throughout the DNA $(1,4,5)$. The tracts are transcribed and the resulting $(r A)_{25}$ is found near the 3 '-end of mRNAs $(1,5)$.

The (dA.dT)-rich sequences of animal nuclear DNA have been characterized by Shenkin and Burdon (2) using hybridization with poly $(r U)$ and by Birnboim $(6,7)$ using pyrimidine tract analysis. Abbreviation: SSC, $0.15 \mathrm{M} \mathrm{NaCl}, 0.015 \mathrm{M}$ sodium citrate ( $\mathrm{pH} 7.0$ ). 
Pyrimidine tract analysis obviously does not measure pure $(\mathrm{dT})_{\mathrm{n}}$ tracts alone and our recent results (8) have shown that the stability of poly(rU).DNA complexes does not give accurate values of the size of (dA.dT) $n$ tracts in DNA either. We have obtained evidence, however, suggesting that the thermal stability of poly (rA).DNA hybrids can be used for this purpose (8). Using this technique, we have found that $0.006 \%$ of the nuclear DNA of calf and 0.0158 of that of rabbit consists of (dT) 20 tracts and that 0.0148 of Physarum polycephalum nuclear DNA consists of $(d T)_{25}$ tracts.

The presence of the $(\mathrm{dA} . \mathrm{dT})_{25}$ tract in essentially all transcriptional units of Dictyostelium poses the question whether this is a general feature of transcription in eukaryotes. In this paper we show that several lower eukaryotes have only a low frequency of these tracts, which is inconsistent with such a general mechanism.

METHODS AND MATERIALS

Labelled poly ( $r A$ )

${ }^{32} \mathrm{P}-$ labelled and ${ }^{3} \mathrm{H}$-labelled poly $(\mathrm{rA})$ were synthesized with Escherichia coli RNA polymerase in a poly(dT)-directed, oligo$(r A)_{5}$-primed polymerization of ${ }^{32}$-labelled or ${ }^{3} \mathrm{H}$-labelled ATP (purchased from The Radiochemical Centre, Amersham, U.K., specific activity 5 and $20 \mathrm{Ci} / \mathrm{mmol}$, respectively) as described in ref. 9 .

\section{Preparation of DNAs}

Nuclear DNAs from duck, Xenopus, monkey (BSCl cells), Dictyostelium (8), yeast (10) and P. polycephalum (11) were extracted from whole-cell lysates or purified nuclei and further purified by standard methods involving phenol extraction (see e.g. (12)), in some cases followed by two cycles of sodium iodide equilibrium centrifugation, ribonuclease treatment and hydroxyapatite chromatography. The preparation of E. coli (13), bacteriophage $\mathrm{T}_{4}$ (14) and bacteriophage $\mathrm{T}_{7}$ (14) DNAs has been described. Trypanosomal nuclear and kinetoplast DNAs were extracted as described in (15) and further purified as described above. Total calf-thymus DNA (type la) was a product of sigma and poly- 
(dT) was purchased from Miles.

Determination of molecular weights of native DNAs

This was carried out by electrophoresis in 0.58 agarose $\mathrm{slab}$ gels using phage $\mathrm{T}_{7}$ DNA, phage $\Phi 29$ DNA and the five cleavage products of phage $\Phi 29$ DNA given by the endonuclease EcoRl as markers (e.g. $(16))$.

Quantitation of large (dA.dT) $\mathrm{n}$ tracts in eukaryotic DNAs

A method was followed involving hybridization of labelled poly $(r A)$ to filter-bound denatured DNA, digestion of non basepaired poly(rA) with ribonuclease $\mathrm{T}_{2}$, thermal melting of the hybrid in $0.1 \mathrm{M} \mathrm{CsCl}$ and comparison of the $\mathrm{T}_{\mathrm{m}}$ with those of the model system poly $(r A) . o l i g o(d T)_{n}$ as described in an earlier paper (8).

Chromatographic behaviour of DNA containing long (dA.dT) clusters on poly(rU) Sephadex

Unbound DNA was eluted with $3 \mathrm{ml} 2 \mathrm{M} \mathrm{LiCl-0.5 \%}$ sodium dodecylsulphate, $10 \mathrm{mM}$ Tris $(\mathrm{pH} 7.5)$ and the bound fraction was eluted step-wise with the same concentrations of sodium dodecylsulphate and Tris, containing $1 \mathrm{M}, 0.5 \mathrm{M}$ and $0.1 \mathrm{M} \mathrm{LiCl,} \mathrm{respectively,}$ ( $3 \mathrm{ml}$ per step) as described in the text. ${ }^{32} \mathrm{p}$-labelled samples were then counted by measuring the Cerenkov radiation. Sodium dodecylsulphate was precipitated by addition of $1 \mathrm{M} \mathrm{KCl}$ and the precipitate was removed by centrifugation (10 min at $1000 \mathrm{~g})$. The supernatant was filtered through a Sartorius nitrocellulose filter (pore size, $0.1 \mu \mathrm{m}$ ) and the filtrate dialysed against two changes of $10 \mathrm{mM}$ Tris $(\mathrm{pH} 7.5)$. DNA was denatured and fixed to nitrocellulose filters (pore size, $0.1 \mu \mathrm{m}$ ) as described (17). Just before the ficoll step, the filters were placed in a $0.1 \mathrm{x}$ SSC-0.018 sodium dodecylsulphate solution containing $20 \mathrm{\mu g}$ ribonuclease $A$ per $\mathrm{ml}$ and incubated for $1 \mathrm{~h}$ at $30^{\circ} \mathrm{C}$, to degrade the poly(rU) contaminating the DNA preparation (this step is essential to avoid high blancs). Finally, the filters were extensively washed with $0.1 \mathrm{M} \mathrm{CsCl}, 0.058$ sodium dodecylsulphate, $5 \mathrm{mM}$ Tris $(\mathrm{pH} 7.5)$ and the filter-bound DNA was assayed for the presence of (dT) $20-25$ tracts as described in (8). 
RESULTS

The occurrance of large (dA.dT) $\mathrm{n}$ tracts in eukaryotic DNAs To determine the percentage of the DNA in (dA.dT) $n$ tracts, denatured eukaryotic DNAs were hybridized to excess labelled poly $(r A)$ under optimal conditions and non-hybridized poly ( $r A$ ) was removed by ribonuclease $\mathrm{T}_{2}$ digestion. To assess the size of the oligo(dT) $n$ sequence in hybrid, its melting point was compared with that of poly $(r A) . o l i g o(d T)_{n}$. We have recently shown that this model system yields the correct value for the length of the $(\mathrm{dT})_{25}$ tracts in the nuclear DNA of the slime mold Dictyostelium discoideum and from theoretical considerations we have concluded that it should be suitable for determining the length of $(d T)_{n}$ tracts in DNA in general (8).

Table I compiles the calculated size and frequency of $(d T)_{n}$ tracts in the nuclear DNAs of some primitive eukaryotes. The nuclear DNAs of the slime molds D. discoideum and P. polycephalum both contain about the same number of $(\mathrm{dT})_{\mathrm{n}}$ tracts of approximately 25 residues. Their frequencies differ by a factor 20 , however, because of the higher DNA content of Physarum per nucleus. Both the nuclear and kinetoplast DNA of trypanosome species of Trypanosoma brucei contain (dT) 20 tracts in high frequency. The nuclear DNAs of the yeast saccharomyces cerevisiae and the trypanosome Crithidia luciliae show a low but significant hybridization to poly $(r A)$, indicating $(d T)_{20-25}$ tracts at a 10-fold lower frequency than in the slime molds.

As a control we have tested three prokaryotic DNAs for the presence of (dT) 20-25 tracts. Table I shows that none of them contains such large tracts. A similar conclusion was reached by Shenkin and Burdon (2), based on the absence of poly(rU) hybridization to these DNAs.

The distribution of large (dA.dT) $\mathrm{n}$ tracts in eukaryotic DNAs We have recently shown that duplex DNA containing (dA.dT) clusters can be bound to poly(rU) Sephadex as a (dA.dT.rU) triple helix (18). This property can be utilized to measure the distribution of the (dA.dT) clusters in the eukaryotic genome by applying high-molecular-weight DNA to the column since all DNA linked to the clusters will also be bound. A pre-requisite of 
TABLE I - LARGE (dA.dT) $\mathbf{n}$ TRACTS IN NATURAL DNAs

1-10 $\mathrm{\mu g}$ denatured filter-bound DNA was hybridized to excess ${ }^{32}$ P-labelled or ${ }^{3} \mathrm{H}-1$ abelled poly(rA) (specific activity, 200-1300 cpm/pmole). The reaction was complete within $3 \mathrm{~h}$ (the ribopolymer concentration was saturating, since an increase in its concentration did not alter the hybridization plateau). The hybrids were incubated with ribonuclease $T_{2}$ (specific activity, $0.1 \mathrm{U} / \mu \mathrm{g}$ protein; 1 unit enzyme solubilizes 1 pmole poly(rA) in $2 \mathrm{~h}$ at $25^{\circ} \mathrm{C}$ ), melted in $0.1 \mathrm{M} \mathrm{CsCl}$ and their $\mathrm{T}_{\mathrm{m}}$ 's were used to calculate the size of the poly ( $\mathrm{rA}$ ) binding site as described $(8)$. The $T_{m}$ of the hybrid of denatured Dictyostelium DNA and poly (rA) has been measured five times and was always $38+1^{\circ} \mathrm{C}$, leading to a calculated binding site of $24+1$ (dT) residues. Similar experiments using 32 p-labelled DNAs from yeast, $C$. luciliae and bacteriophage $T_{7}$ have shown that $>988$ of the input DNA binds to the nitrocellulose filter and remains bound to it during the hybridization procedure.

\begin{tabular}{|c|c|c|c|c|c|c|}
\hline \multirow{3}{*}{$\begin{array}{l}\text { Dictyostelium (nuclear) } \\
\text { Dictyostelium (nuclear) }\end{array}$} & \multirow{2}{*}{$\begin{array}{l}\begin{array}{c}\text { DNA hybridized } \\
\text { to poly(rA) } \\
\text { (mole } 8)\end{array} \\
0.30\end{array}$} & \multirow{2}{*}{$\begin{array}{l}\text { Calculated } \\
\text { tract size } \\
24\end{array}$} & \multicolumn{2}{|c|}{$\begin{array}{c}\text { Analytical } \\
\text { complexity } \\
\text { of DNA } \phi \\
\left(\times 10^{-10}\right)\end{array}$} & \multirow{2}{*}{\multicolumn{2}{|c|}{$\begin{array}{c}\begin{array}{c}\text { Number of } \\
\text { tracts per } \\
\text { genome } \\
(\nabla)\end{array} \\
11300\end{array}$}} \\
\hline & & & 3 & $(28)$ & & \\
\hline & 0.33 & - & & & & 500 \\
\hline Physarum polycephalum (nuclear) & 0.014 & 26 & 40 & (11) & 6 & 500 \\
\hline Saccharomyces cerevisiae (nuclear) & 0.039 & 20 & 1.3 & (29) & & 800 \\
\hline Crithidia luciliae (nuclear) & 0.005 & - & 7 & $(30,31)$ & & $500^{*}$ \\
\hline Trypanosoma brucei (nuclear) & 0.18 & 20 & 5 & $(t)$ & 13 & 600 \\
\hline Trypanosoma brucel (kinetoplast) & 0.66 & 20 & 0.5 & $(t)$ & & 000 \\
\hline Escherichia coli & $<0.001$ & - & 0.27 & (3) & & $0^{*}$ \\
\hline Bacteriophage $T_{7}$ & $<0.001$ & - & 0.0025 & $(32)$ & & $0^{*}$ \\
\hline Bacteriophage $T_{4}$ & $<0.001$ & - & 0.011 & (32) & & $0^{*}$ \\
\hline Poly (dT) & 95 & $>100$ & & & & \\
\hline
\end{tabular}

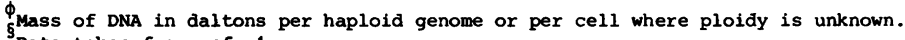

Data taken from ref. 1 .

$t^{n}=20$.

Calculated from refs 33 and 34 .

To nearest 100 tracts.

this approach is that the elution position of the (dA.dT) cluster is independent of the molecular weight of the DNA applied and of the number of clusters per molecule. In order to test this we analysed the chromatography of Dictyostelium DNA of 25 $\times 10^{6}$ daltons and the same preparation sheared to $1.3 \times 10^{6}$ daltons on poly(rU) Sephadex (Fig. 1). 908 of the high-molecularweight DNA was retained by the column and eluted in the 0.1-M LiCl fraction, consistent with the gradient elutions already presented (18). Of the sheared DNA only 228 eluted in the 0.1-M Licl fraction. A similar chromatography was performed with DNA sonicated to a fragment size of $2 \times 10^{6}$ daltons and the DNA present in the different column fractions was hybridized to poly(rA) to determine the elution position of the (dA.dT) 25 tracts (Table II). 808 of the total hybridization was found with the $0.1-M$ fraction and the remaining 208 with the intermediate fraction. Melting analysis shows that poly(rA) hybridizes exclusively to the $(d T)_{25}$ tracts present in both fractions. From this 


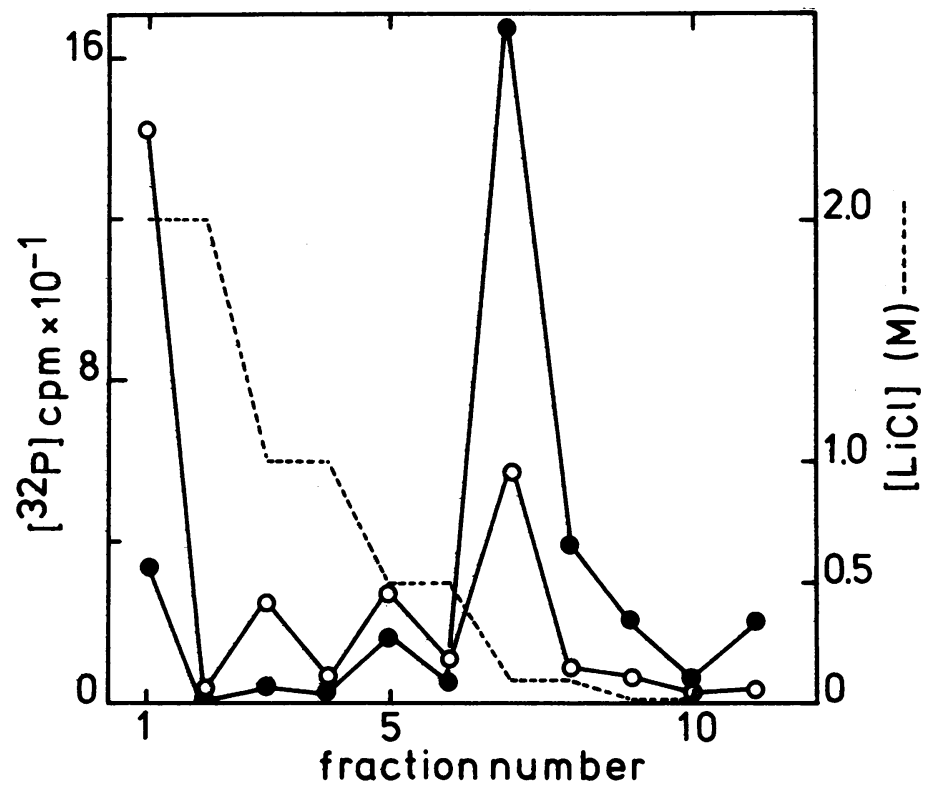

Fig. 1 - Fractionation of Dictyostelium nuclear DNA on a poly(rU) Sephadex column. High-molecular-weight (circa $3 \times 10^{7}, \bullet$ ) or sheared (circa $1.3 \times$ $\left.10^{6}, 0-0\right)$ Dictyostelium DNA was applied to a poly ( $\mathrm{rU}$ ) Sephadex column and

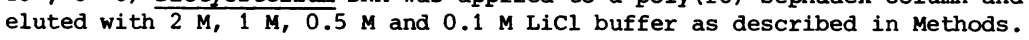

\section{TABLE II - ELUTION OF (dA.dT) 25 TRACTS UPON CHROMATOGRAPHY OF SONICATED} Dictyostelium DNA ON POLY(rU) SEPHADEX

$0.8 \mu \mathrm{g}{ }^{32} \mathrm{p}$-labelled Dictyostelium DNA (specific activity, $1000 \mathrm{cpm} / \mu \mathrm{g}$ ) was sonicated to a mean fragment size of about $2 \times 10^{6}$ daltons (calculated from sedimentation through a neutral sucrose gradient). The DNA was hybridized to a poly (rU) Sephadex column (see (18)) in $2 \mathrm{M} \mathrm{LiCl}$ and the bound fraction was eluted step-wise with $0.5 \mathrm{M}$ and $0.1 \mathrm{M} \mathrm{LiCl}$ ( $3 \mathrm{ml}$ per step). Part of the DNA samples was fixed to nitrocellulose filters as described in Methods and hybridized to ${ }^{-3} \mathrm{H}-1$ abelled poly $(\mathrm{rA})$ (specific activity, $1300 \mathrm{cpm} / \mathrm{pmole}$ ) as described in (8). (All data have been corrected for aspecific binding of poly$(r A)$ to a filter containing an equivalent amount of bacteriophage $T_{7}$ DNA $1 \mathrm{\mu g}$ phage $T_{7}$ DNA binds about $60 \mathrm{cpm}$ of labelled ribopolymer.) Between $40 \%$ and $60 \%$ of the input DNA was recovered on the filters after the hybridization. The hybrids were then melted in $0.1 \mathrm{M} \mathrm{CsCl}$ and the $\mathrm{T}_{\mathrm{m}}$ was used to calculate the size of the $(d T)_{n}$ tract involved in the binding of poly $(r A)$ as described in (8).

\begin{tabular}{|c|c|c|c|c|}
\hline & \multicolumn{3}{|c|}{ Fraction } & \multirow{2}{*}{$\begin{array}{l}\text { Unfractionated } \\
\text { high-molecular- } \\
\text { weight DNA }\end{array}$} \\
\hline & $2 \mathrm{M} \mathrm{LiCl}$ & $0.5 \mathrm{M} \mathrm{LiCl}$ & $0.1 \mathrm{M} \mathrm{LiCl}$ & \\
\hline $\begin{array}{l}32 \text { p-labelled DNA in } \\
\text { different fractions } \\
\text { ( } 8 \text { of input) }\end{array}$ & 49 & 19 & 32 & \\
\hline $\begin{array}{l}\text { Hybridization of } \\
\text { filter-bound DNA } \\
\text { to poly }(r A) \text { ( } 8)\end{array}$ & $<0.01$ & 0.2 & 0.7 & 0.3 \\
\hline $\begin{array}{l}\text { Mean distribution of } \\
(\mathrm{dA} \cdot \mathrm{dT})_{25} \text { tracts }\end{array}$ & & $\begin{aligned} 1 & \text { per } \\
8.1 & \times 10^{6}\end{aligned}$ & $\begin{aligned} 1 & \text { per } \\
2.3 & \times 10^{6}\end{aligned}$ & $\begin{aligned} 1 & \text { per } \\
5.4 & \times 10^{6}\end{aligned}$ \\
\hline
\end{tabular}


TABLE III - BINDING OF EUKARYOTIC DNAS TO POLY(rU) SEPHADEX

For details, see Methods.

\begin{tabular}{|c|c|c|c|c|}
\hline \multirow[b]{2}{*}{ DNA. } & \multirow[b]{2}{*}{$\begin{array}{c}\text { Molecular } \\
\text { weight } \\
\left(\times 10^{-6}\right)\end{array}$} & \multicolumn{3}{|c|}{ \& Binding } \\
\hline & & $\begin{array}{l}1 \mathrm{M} \mathrm{LiCl} \\
\text { fraction } \\
\text { (found) }\end{array}$ & $\begin{array}{c}0.1 \mathrm{M} \mathrm{LiCl} \\
\text { fraction } \\
\text { (found) }\end{array}$ & $\begin{array}{c}0.1 \mathrm{M} \mathrm{LiCl} \\
\text { fraction } \\
\text { (calculated) }\end{array}$ \\
\hline Duck nuclear & 30 & 25 & 59 & \\
\hline Xenopus nuclear & 22 & 40 & 27 & \\
\hline Calf total & 7 & 19 & 14 & $7^{\S}$ \\
\hline Yeast nuclear & 30 & 17 & 60 & 100 \\
\hline c. luciliae nuclear & 30 & 27 & 18 & 20 \\
\hline r. brucei nuclear & 30 & 43 & 40 & 100 \\
\hline Bacteriophage $\mathrm{T}_{4}$ & 30 & 0 & $<3$ & 0 \\
\hline
\end{tabular}

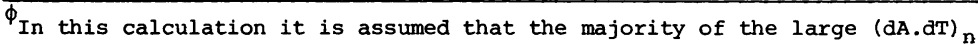
tracts elutes in the $0.1-\mathrm{M} \mathrm{LiCl}$ fraction and that these tracts are randomly distributed over the entire genome.

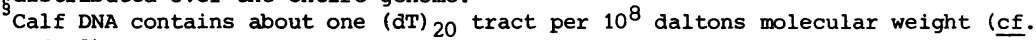
ref. 8).

experiment we may conclude that the majority of the (dA.dT) 25 tracts are eluted in the same fraction regardless of the molecular weight of the DNA and that the number of (dA.dT) 25 tracts per molecule only slightly influences their elution molarity, possibly because of cooperative poly(rU) binding when more than one $(d A . d T)_{25}$ tract is present per molecule. Finally, we conclude that the efficiency of retention of (dA.dT) 25 tracts by the column under these conditions is more than 998 . It should be stressed that the frequency of (dA.dT) 25 tracts in the intermediate fraction is far too low to account for the observed

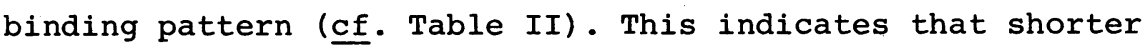
tracts must be involved in the binding of some of these molecules to the poly (rU) column. Whether these shorter tracts are pure remains to be established.

We then measured the binding of a series of eukaryotic DNAs of known molecular weight to the poly(rU) column. Because many of these DNAs have slightly shorter tracts than Dictyostelium DNA (Table I and (8)) we eluted the column with steps of $2 \mathrm{M}$, $1 \mathrm{M} \mathrm{LiCl}$ and recovered the DNA containing large tracts with 0.1 $M$ LiCl. The results are shown in Table III. Significant amounts of high-molecular-weight DNAs from both lower and higher eukaryotes are tightly bound to the poly(rU) Sephadex column, showing that the (dA.dT) clusters must be widely dispersed in their genomes rather than clustered in a small segment. 


\section{DISCUSSION}

The results presented in Table I clearly show that the presence of a high frequency of (dA.dT) 20-25 tracts, available for hybridization with poly $(\mathrm{rA})$, is not a constant feature of the nuclear DNAs of primitive eukaryotes. Whereas 0.38 of Dictyostelium DNA hybridizes to poly ( $r A)$, only $0.005 \%$ of Crithidia nuclear DNA does. Two trivial explanations for the low hybridization of poly $(r A)$ to Crithidia DNA should be considered. First, (dA.dT)rich DNA containing the $(\mathrm{dT})_{\mathrm{n}}$ tracts of interest might have been specifically lost in the nitrocellulose step, because poly (dA) does not bind to nitrocellulose in $3 \mathrm{x}$ SSC (2). Second, large (dT) $\mathrm{n}$ tracts might be present, but unavailable for base pairing with poly $(r A)$ because they are adjacent to (dA) $n$ tracts, leading to the formation of (dA.dT) $n$ hairpins after denaturation. The first possibility is rendered unlikely by the fact that long DNA was used in these experiments and that $>98 \%$ of denatured Crithidia DNA bound to nitrocellulose filters and remained bound during the hybridization. Moreover, identical results were obtained if the DNA was applied to a filter in $2 \mathrm{M} \mathrm{NaCl}$, a condition that allows poly $(d A)$ to bind to nitrocellulose (19). The second possibility is rendered unlikely because only a small fraction (18\%) of high-molecular-weight Crithidia DNA elutes from a poly(rU) Sephadex column between $1 \mathrm{M}$ and $0.1 \mathrm{M} \mathrm{LiCl}$ (Table III), indicative of a low frequency of large (dA.dT) $n$ tracts (cf. Table II). (The presence of such clustered (dA.dT) $n$ tracts does not influence this technique.) We, therefore, conclude that the presence of a high frequency of (dA.dT) $20-25$ tracts is not an obligatory characteristic of the nuclear DNAs of primitive eukaryotes. The suggested involvement of these tracts in the termination of transcription, the post-transcriptional attachment of oligo(rA) 100 to the 3'-terminus of mRNAs (1) or in the transport of mRNAs to the cytoplasm (20), in Dictyostelium, therefore, does not extend to the majority of the transcribing units in other primitive eukaryotes.

The kinetoplast DNA of T. brucei gives the highest hybridization with poly(rA) of all natural DNAs studied until now (see also (2) and (21)). This unusual DNA predominantly consists of a large network of catenated mini-circles with a contour length 
of $0.33 \mu \mathrm{m}$ (see (22)), equivalent to a molecular weight of 0.66 $x 10^{6}$. Restriction enzyme analysis has shown that these minicircles are heterogeneous in base sequence (23), as previously shown for the mini-circles of c. luciliae (24). In addition, the kinetoplast DNA network contains a more complex "maxi-circle" component (ㄷ․ (24)) with an estimated complexity of $13 \times 10^{6}$ daltons (23). Further experiments are required to establish whether the (dA.dT) 20 tracts are present on the maxi-circles or mini-circles and whether they can be used to fractionate the kinetoplast DNA components on poly(rU) Sephadex columns.

We have shown that the majority of the $(\mathrm{dA} . \mathrm{dT})_{25}$ tracts present in Dictyostelium DNA elute from a poly(rU) Sephadex column between $0.5 \mathrm{M}$ and $0.1 \mathrm{M} \mathrm{LiCl}$. Although Dictyostelium DNA appears to be bound to poly(rU) Sephadex mainly by the (dA.dT) 25 tracts we cannot formally exclude that binding of this or other DNAs also additionally occurs via cooperative effects of shorter (dA.dT) clusters. Calculation of the expected binding in the $0.1-$ $M$ fraction, assuming a random distribution of these clusters in the lower eukaryotes, however, gives a value in reasonable agreement with the experimental measurements, suggesting that these cooperative effects are unimportant. We have also found that the distribution of ( $\mathrm{dA} . \mathrm{dT}$ ) clusters in rabbit DNA is consistent with a random distribution (Flavell, R.A., Van den Berg, F.M. and Grosveld, G.C., unpublished).

Finally, we have observed extensive binding to poly(rU) Sephadex of nuclear DNAs of a series of higher eukaryotes from Xenopus to rabbit, showing that a wide-spread distribution of (dA.dT) clusters throughout the genome is a general phenomenon in the DNA of higher eukaryotes. At least some of these (dA.dT) clusters have been shown to be transcribed into homopolymer regions in human $(25,26)$ and sea urchin (27) HnRNA, but it is unclear whether these clusters are functionally related to the (dA.dT) 25 tracts of Dictyostelium. To resolve this question we are at present studying the transcriptional activity of the homopolymer containing DNA segments of mammalian DNA obtained by poly(rU) Sephadex chromatography. 


\section{ACKNOWLEDGEMENTS}

We thank Ms E. De Boer and H.J.Kwant-den Harink for technical assistance and Mr F.M. Van den Berg for performing the experiments shown in Fig. 1. We also thank Mrs F.Fase-Fowler for gifts of duck, phage $T_{4}$, phage $T_{7}$ and Crithidia DNA, Dr A.H.Fairlamb for $T$. brucei DNA and Dr R.Charles for help with the preparation of Xenopus DNA. This work was supported in part by a grant from The Netherlands Foundation for Chemical Research (SON) with financial aid from The Netherlands Organization for the Advancement of Pure Research (ZWO).

\section{REFERENCES}

Jacobson, A., Firtel, R.A. and Lodish, H.F. (1974) Proc.Natl.Acad.Sci.U.S. 71, 1607-1611.

Shenkin, A. and Burdon, R.H. (1974) J.Mol.Biol. 85, 19-39.

Bishop, J.O., Rosbash, M. and Evans, D. (1974) J.Mol.Biol. 85, 75-86.

Firtel, R.A. and Lodish, H.F. (1973) J.Mol.Biol. 79, 295-314.

Firtel, R.A., Kindle, K. and Huxley, M.P. (1976) Fed.Proc. 35, 13-22.

Birnboim, H.C., Mitchel, R.E.J. and Straus, N.A. (1973) Proc.Natl.Acad. Sci.U.S. 70, 2189-2192.

7 Birnboim, H.C. and Sederoff, R. (1975) Cell 5, 173-181.

8 Mol, J.N.M. and Borst, P. (1976) Nucleic Aciōs Res. 3, 1029-1051.

9 Van Kreijl, C.F. and Borst, P. (1973) Biochem.Biophys.Res.Commun. 54, 1724.

Hollenberg, C.P., Borst, P. and Van Bruggen, E.F.J. (1970) Biochim.Biophys.Acta 209, 1-15.

Fouquet, H., Bierweiler, B. and Sauer, H.W. (1974) Europ.J.Biochem. 44 , 407-410.

Sanders, J.P.M., Flavell, R.A., Borst, P. and Mol, J.N.M. (1973) Biochim. Biophys.Acta 312, 441-457. Marmur, J. (1961) J.Mol.Biol. 3, 208-218.

Yamamoto, K.R., Alberts, B.M., Benzinger, R., Lawhorne, L. and Treiber, G. (1970) Virology 40, 734-744.

15 Steinert, M., Van Assel, S., Borst, P., Mol, J.N.M., Kleisen, C.M. and Newton, B.A. (1973) Exptl.Cell Res. 76, 175-185.

Sanders, J.P.M., Borst, P. and Weijers, P.J. (1975) Mol.Gen.Gen. 143, 5364.

17 Flavell, R.A., Birfelder, E.J., Sanders, J.P.M. and Borst, P. (1974) Europ.J.Biochem. 47, 535-543.

Flavell, R.A. and Van den Berg, F.M. (1975) FEBS Letters 58, 90-93.

Pero, R.W., Bryngelsson, T., Bryngelsson, C., Deutsch, A., Nordén, $\AA$. and Norgren, A. (1975) Nucleic Acids Res. 2, 1163-1176.

Firtel, R.A. and Pederson, T. (1975) Proc.Natl.Acad.Sci.U.S. 72, 301-305. Marshall, S. and Gillespie, D. (1972) Nature New Biol. 240, 43-45. Borst, P. (1976) in Handbook of Biochemistry and Molecular Biology, Fasman, G.D., Ed. , 3rd edn, Vol. 2, CRC Press, Cleveland, Ohio, pp. 375378.

Borst, P., Fairlamb, A.H., Fase-Fowler, F., Hoeijmakers, J.H.J. and Weislogel, P.O. (1976) in The Genetic Function of Mitochondrial DNA, Saccone, C. and Kroon, A.M., Eds, North-Holland, Amsterdam, in press. Kleisen, C.M. and Borst, P. (1975) Biochim.Biophys.Acta 407, 473-478. Nakazato, H., Kopp, D.W. and Edmonds, M. (1973) J.Biol.Chem. 248, 14721476 .

Molloy, G.R., Jelinek, W., Salditt, M. and Darnell, J.E. (1974) Cell 1 , 43-53.

Dubroff, L.M. and Nemer, M. (1975) J.Mol.Biol. 95, 455-476. 
28 Firtel, R.A. and Bonner, J. (1972) J.Mol.Biol. 66, 339-361.

29 Sober, H.A., Ed. (1970) Handbook of Biochemistry: Selected Data for Molecular Biology, The Chemical Rubber Co., Cleveland, Ohio, p. H-104.

30 Steinert, M., Van Assel, S. and Steinert, G. (1969) Exptl.Cell Res. 56, 69-74.

31 Laurent, M., Van Assel, S. and Steinert, M. (1971) Biochem.Biophys.Res. Commun. 43, 278-284.

32 Freifelder, D. (1970) J.Mol.Biol. 54, 567-577.

33 Newton, B.A. and Burnett, J.K. (1972) in Comparative Biochemistry of Parasites, Van den Bossche, H., Ed., Academic Press, New York, pp. 185197.

34 Newton, B.A. (1975) Trans.Roy.Soc.Trop.Med.Hyg. 69, 268-269. 